CLINICAL STUDY

\title{
Fatigue and fatigue-related symptoms in patients treated for different causes of hypothyroidism
}

\author{
Marloes Louwerens ${ }^{1}$, Bente C Appelhof ${ }^{3}$, Herman Verloop ${ }^{1}$, Marco Medici ${ }^{4}$, Robin P Peeters ${ }^{4}$, Theo J Visser ${ }^{4}$, \\ Anita Boelen ${ }^{3}$, Eric Fliers ${ }^{3}$, Johannes W A Smit ${ }^{1}$ and Olaf M Dekkers ${ }^{2}$ \\ Departments of ${ }^{1}$ Endocrinology and ${ }^{2}$ Clinical Epidemiology C7-99, Leiden University Medical Center, PO Box 9600, 2300 RC Leiden, The Netherlands, \\ ${ }^{3}$ Department of Endocrinology and Metabolism, Academic Medical Center of the University of Amsterdam, Amsterdam, The Netherlands and ${ }^{4}$ Department \\ of Endocrinology, Erasmus University Medical Center, Rotterdam, The Netherlands \\ (Correspondence should be addressed to O M Dekkers; Email: o.m.dekkers@lumc.nl)
}

*(M Louwerens, B C Appelhof and H Verloop contributed equally to this work)

\begin{abstract}
Objective: Research on determinants of well-being in patients on thyroid hormone replacement therapy is warranted, as persistent fatigue-related complaints are common in this population. In this study, we evaluated the impact of different states of hypothyroidism on fatigue and fatigue-related symptoms. Furthermore, the relationship between fatigue and the TSH receptor (TSHR)-Asp727Glu polymorphism, a common genetic variant of the TSHR, was analyzed.

Design: A cross-sectional study was performed in 278 patients (140 patients treated for differentiated thyroid carcinoma (DTC) and 138 with autoimmune hypothyroidism (AIH)) genotyped for the TSHR-Asp727Glu polymorphism.

Methods: The multidimensional fatigue inventory (MFI-20) was used to assess fatigue, with higher MFI-20 scores indicating more fatigue-related complaints. MFI-20 scores were related to disease status and Asp727Glu polymorphism status.

Results: AIH patients scored significantly higher than DTC patients on all five MFI-20 subscales $(P<0.001)$, independent of clinical and thyroid hormone parameters. The frequency of the TSHR-Glu727 allele was $7.2 \%$. Heterozygous DTC patients had more favorable MFI-20 scores than wild-type DTC patients on four of five subscales. The modest effect of the TSHR-Asp727Glu polymorphism on fatigue was found in DTC patients only.

Conclusions: AIH patients had significantly higher levels of fatigue compared with DTC patients, which could not be attributed to clinical or thyroid hormone parameters. The modest effect of the TSHR-Asp727Glu polymorphism on fatigue in DTC patients should be confirmed in other cohorts.
\end{abstract}

European Journal of Endocrinology 167 809-815

\section{Introduction}

Awareness of psychological and physical dysfunction in patients on thyroid hormone therapy is important. Many hypothyroid patients experience persistent fatigue and fatigue-related symptoms, as well as poor performance on various domains of neurocognitive functioning, despite apparently adequate replacement therapy $(1,2)$. The origin of hypothyroidism, and also genetic variation in thyroid hormone pathway genes and variation in local thyroid hormone profile, may be of importance to explain these findings.

TSH plays a central role in regulation of thyroid function and exerts its effects through binding to the TSH receptor (TSHR). Although primarily expressed on thyroid follicular cells, evidence suggests TSHR expression in the anterior pituitary, adipose tissue, retro-orbital tissue, osteoblasts, the immune system, and cardiac muscle $(3,4,5,6,7,8,9,10)$. In addition, expression of TSHR mRNA has been reported in several regions of the mammalian, including human, brain $(11,12,13,14,15)$. These findings indicate that the role of TSH is not merely restricted to hypothalamuspituitary-thyroid axis regulation $(7,8,15,16,17)$.

The TSHR-Asp727Glu polymorphism is a common genetic variant, leading to an amino acid substitution in the intracellular domain of the TSHR (18). The TSHR-Glu727 variant has been proposed to have higher activity than the wild-type variant because less TSH is required to maintain normal serum free thyroxine $\left(\mathrm{FT}_{4}\right)$ levels $(19,20,21)$, indicating higher sensitivity of the receptor. Previous reports have assessed the effect of the TSHR-Asp 727Glu polymorphism on various clinical outcomes, including bone metabolism, glucose metabolism, and preeclampsia $(21,22,23,24)$. Furthermore, a TSHR-mediated mechanism was proposed to be 
involved in stimulation of type 2 iodothyronine deiodinase (D2) expression in various tissues (7, 8, 15). This process may be an important determinant of the local concentration of the biologically active thyroid hormone triiodothyronine $\left(\mathrm{T}_{3}\right)$ as $\mathrm{D} 2$ catalyzes the conversion of $\mathrm{T}_{4}$ to $\mathrm{T}_{3}$ (25). It could be hypothesized that in the CNS of individuals with the TSHR-Glu727 variant, a more sensitive TSHR increases the ability of neurons to adjust intracellular thyroid hormone levels, thereby affecting neuropsychological functioning.

The aim of this study was to assess the impact of the cause of hypothyroidism on fatigue and fatiguerelated symptoms in two independent cohorts of patients treated for hypothyroidism of different origin, i.e. thyroidectomized patients treated for differentiated thyroid carcinoma (DTC) and patients with autoimmune hypothyroidism (AIH). Secondly, it was studied whether an effect of the TSHR-Asp727Glu polymorphism on fatigue and fatigue-related symptoms could be found.

\section{Materials and methods}

\section{Study design and study population}

We performed a cross-sectional study in patients on thyroid hormone replacement therapy for hypothyroidism for either DTC or AIH (Fig. 1). The present analyses were based on previously included and phenotyped cohorts $(22,26)$, which therefore determined the sample size (27).

The study comprised 292 patients: 149 patients treated for DTC from Leiden University Medical Centre and 143 patients with AIH from the Academic Medical Centre of the University of Amsterdam. Written informed consent was provided by all patients and the institutional review boards approved the study. Fourteen patients were excluded: genotyping failed

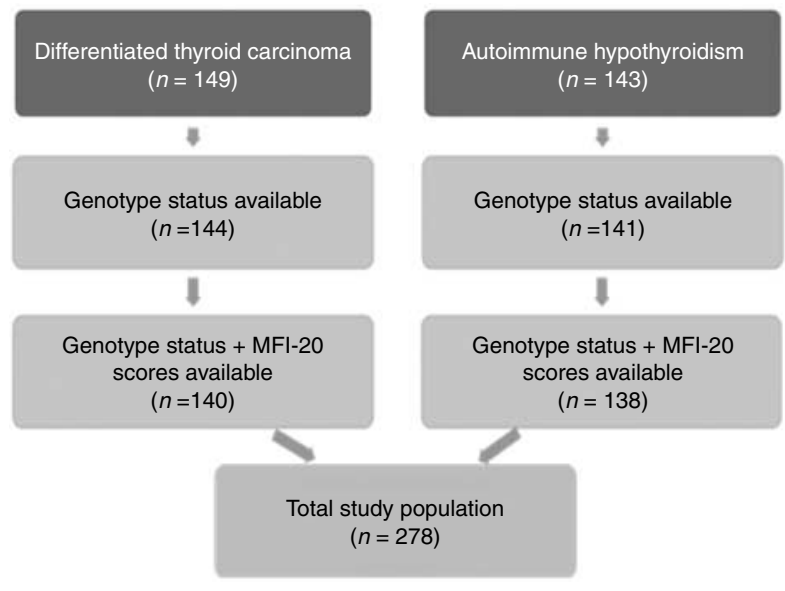

Figure 1 Flow chart of included patients. in seven patients and seven additional patients did not return the fatigue questionnaire. A total of 278 patients were included to assess the relationship between fatigue questionnaire scores and genotype status (Fig. 1).

All DTC patients had been treated by total thyroidectomy followed by routine postoperative radioiodine ablation therapy and were without signs of persistent or recurrent disease at time of evaluation (22). The diagnosis of AIH was based on biochemically proven hypothyroidism, measurement of TPO antibodies, and exclusion of secondary causes (28). Patients in both cohorts were on thyroid hormone replacement therapy. In DTC patients, thyroid hormone replacement therapy was aimed at TSH suppression to prevent disease recurrence, while for $\mathrm{AIH}$ the target for $\mathrm{T}_{4}$ replacement was a TSH in the reference range (RR).

\section{Fatigue questionnaire}

The multidimensional fatigue inventory (MFI-20) was used to assess fatigue. The MFI-20 is a 20-item selfreport questionnaire covering five dimensions of fatigue, which are measured on a five-point scale. The five dimensions are general fatigue, physical fatigue, reduction in activities, reduction in motivation, and mental fatigue. 'General fatigue' includes general statements concerning a person's functioning such as 'I feel rested'. 'Physical fatigue' refers to the physical sensation of feeling tired. Somatic symptoms, such as light-headedness or sore muscles, are not included in the scale in order to exclude potential contamination with the symptoms of somatic illness, independent of fatigue. Reduction in activities and lack of motivation to start any activity are covered by the scales 'Reduced activities' and 'Reduced motivation' respectively. Finally, cognitive symptoms such as having difficulties concentrating are included in the scale for 'Mental fatigue'. Scores vary from 0 to 20; higher scores indicate greater fatigue $(29,30)$.

\section{Genotyping}

For genotyping of the TSHR-Asp727Glu polymorphism, DNA was isolated from peripheral leucocytes by the salting out procedure (31). Genotyping was performed using $5 \mathrm{ng}$ genomic DNA by a 50-fluorogenic TaqMan assay and reactions were performed in 384-wells format on ABI9700 2x384-well PCR machines with end point reading on the ABI 7900HT TaqMan machine (Applied Biosystems, Nieuwerkerk aan den IJssel, The Netherlands). Primer and probe sequences were optimized using the single nucleotide polymorphism assay-by-design service of Applied Biosystems. Genotypes were classified as wild type (Asp/Asp), heterozygous (Asp/Glu), or homozygous (Glu/Glu) for the TSHR-Asp727Glu polymorphism. 


\section{Laboratory examination}

Morning blood samples were drawn before thyroid hormone intake and stored at $-80{ }^{\circ} \mathrm{C}$. In the DTC population, serum $\mathrm{FT}_{4}$ (RR 10-24 pmol/l) and $\mathrm{TSH}$ levels (RR 0.3-4.8 mU/l) were measured by electrochemiluminescence immunoassay using a Modular Analytics E-170 system (intra-assay CV of 1.6-2.2 and $1.3-5.0 \%$ respectively (Roche)). Serum $\mathrm{T}_{3}$ (RR $1.27-2.39 \mathrm{nmol} / \mathrm{l})$ and $\mathrm{T}_{4}(\mathrm{RR} 70-138 \mathrm{nmol} / \mathrm{l})$ were analyzed by RIA. The maximum intra-assay $\mathrm{CV}$ were $5.8\left(\mathrm{~T}_{3}\right)$ and $7.7 \%\left(\mathrm{~T}_{4}\right)$. In the $\mathrm{AIH}$ patients, $\mathrm{FT}_{4}(\mathrm{RR}$ 10-23 pmol/l) was analyzed by fluoroimmunoassay (Delfia P1232 Fluorometer, Perkin Elmer, Waltham, MA, USA). The maximal intra- and interassay variations were 5.1 and $6.8 \%$ respectively. Serum TSH (RR 0.4-4.0 mU/l) was analyzed by solid-phase two-site fluoro-immunometric assay (IFMA, Perkin Elmer). The maximal intra- and interassay variations were $<5$ and $7.7 \%$ respectively. Serum $\mathrm{T}_{3}(\mathrm{RR} \quad 1.3-2.7 \mathrm{nmol} / \mathrm{l})$ and $\mathrm{T}_{4}$ levels (RR 70-150 nmol/l) were measured by RIA (32). The maximal intra- and interassay variations were 6.3 and $7.8 \%\left(\mathrm{~T}_{3}\right)$ and 5.4 and $8.7 \%\left(\mathrm{~T}_{4}\right)$ respectively.

\section{Statistical analysis}

Different $\mathrm{FT}_{4}$, TSH, $\mathrm{T}_{3}$, and $\mathrm{T}_{4}$ assays were used in the two cohorts. In order to obtain comparable RRs, standardized $z$-scores were calculated for thyroid parameters in the DTC cohort. In a second step, these $z$-scores were applied to the RRs of the thyroid parameters in the AIH cohort.

Data are presented as mean \pm s.D., median (range), or proportions as appropriate. Baseline characteristics, thyroid parameters, and MFI-20 scores were categorized by disease (DTC vs AIH) as well as genotype status.
Potential deviations from Hardy-Weinberg equilibrium were assessed by a $\chi^{2}$ test. Differences in clinical parameters and thyroid parameters were analyzed by $t$-tests and $\chi^{2}$ tests, as appropriate. Mean differences (MD) with accompanying 95\% confidence intervals $(95 \%$ CI) were presented for continuous variables. TSH levels were log-transformed to normalize distribution.

The association between MFI-20 scores and disease or genotype status was analyzed by linear regression. All analyses were adjusted for age and gender, and subsequently, BMI, TSH, $\mathrm{T}_{3}, \mathrm{~T}_{4}$, and $\mathrm{FT}_{4}$ were added to the model to account for a potential confounding effect of these factors.

To disentangle effects of diagnosis (DTC vs AIH) on fatigue from effects of the polymorphism, an interaction analysis was performed. Because of the linearity of the regression model used, a significant interaction was interpreted as departure from additivity. Interaction was tested with a Wald test. Statistical analyses were carried out using SPSS 17.0 for windows (SPSS, Inc., Chicago, IL, USA).

\section{Results}

\section{Patient characteristics and MFI-20 scores}

A total of 278 patients were included in the study: 140 treated for DTC and 138 treated for AIH (Table 1). Mean age of all patients was 48.8 years; 233 (84\%) were female. Median duration of cure after treatment for DTC was 6.4 years (range $0.5-41.8$ years). DTC patients were on thyroid hormone replacement therapy for longer than AIH patients (median: 9.2 vs 5.5 years).

As expected, DTC patients had lower TSH levels than AIH patients (median: 0.07 vs $1.20 \mathrm{mU} / \mathrm{l}$ ) and higher $\mathrm{FT}_{4}$ levels $(21.5$ vs $14.7 \mathrm{pmol} / \mathrm{l})$, reflecting a

Table 1 Study characteristics by cause of hypothyroidism. Data are expressed as mean \pm s.D., median (range), or percentage as appropriate.

\begin{tabular}{|c|c|c|c|c|c|}
\hline & $\begin{array}{c}\text { Total population } \\
\quad(n=278)\end{array}$ & $\begin{array}{c}\text { DTC } \\
(n=140)\end{array}$ & $\underset{(n=138)}{\text { AlH }}$ & $\begin{array}{l}\text { Mean differences } \\
(95 \% \mathrm{Cl})\end{array}$ & $P$ value $^{\mathrm{a}}$ \\
\hline \multicolumn{6}{|l|}{ General characteristics } \\
\hline Age (years) & $48.8 \pm 11.6$ & $49.3 \pm 13.3$ & $48.3 \pm 9.8$ & $-1.0(-3.7 ; 1.7)$ & 0.485 \\
\hline Sex (female, \%) & 83.8 & 81.4 & 86.2 & ND & 0.277 \\
\hline BMI $\left(\mathrm{kg} / \mathrm{m}^{2}\right)$ & $27.3 \pm 5.7$ & $25.7 \pm 4.6$ & $28.7 \pm 6.3$ & $3.0(1.7 ; 4.3)$ & $<0.001$ \\
\hline \multicolumn{6}{|c|}{ Thyroid function parameters } \\
\hline $\mathrm{TSH}(\mathrm{mU} / \mathrm{l})$ & $0.49(0.01 ; 6.50)$ & $0.07(0.01 ; 5.35)$ & $1.20(0.04 ; 6.50)$ & $2.31(2.00 ; 2.63)$ & $<0.001^{b}$ \\
\hline $\mathrm{T}_{4}(\mathrm{nmol} / \mathrm{l})$ & $136.3 \pm 38.6$ & $150.6 \pm 45.4$ & $123.6 \pm 25.4$ & $-26.6(-35.5 ;-17.8)$ & $<0.001$ \\
\hline $\mathrm{T}_{3}(\mathrm{nmol} / \mathrm{l})$ & $1.64 \pm 0.38$ & $1.56 \pm 0.42$ & $1.72 \pm 0.32$ & $0.16(0.07 ; 0.25)$ & 0.001 \\
\hline $\mathrm{FT}_{4}(\mathrm{pmol} / \mathrm{l})$ & $17.9 \pm 4.9$ & $21.5 \pm 4.1$ & $14.7 \pm 2.8$ & $-6.8(-7.6 ;-5.9)$ & $<0.001$ \\
\hline $\mathrm{T}_{4}$ dose $(\mu \mathrm{g} / \mathrm{kg})$ & $1.88 \pm 0.88$ & $2.13 \pm 1.02$ & $1.59 \pm 0.65$ & $-0.57(-0.77 ;-0.37)$ & $<0.001$ \\
\hline \multicolumn{6}{|l|}{ MFI-20 scores } \\
\hline General fatigue & $13.1 \pm 5.0$ & $11.0 \pm 4.8$ & $15.1 \pm 4.3$ & $4.0(3.0 ; 5.1)$ & $<0.001$ \\
\hline Physical fatigue & $11.4 \pm 4.8$ & $9.9 \pm 4.9$ & $13.0 \pm 4.1$ & $3.1(2.1 ; 4.2)$ & $<0.001$ \\
\hline Reduced activity & $10.2 \pm 4.6$ & $8.8 \pm 4.1$ & $11.6 \pm 4.6$ & $2.8(1.8 ; 3.9)$ & $<0.001$ \\
\hline Reduced motivation & $9.8 \pm 4.2$ & $8.6 \pm 3.8$ & $11.0 \pm 4.4$ & $2.3(1.4 ; 3.3)$ & $<0.001$ \\
\hline Mental fatigue & $11.1 \pm 5.1$ & $9.5 \pm 4.8$ & $12.7 \pm 4.9$ & $3.0(1.9 ; 4.2)$ & $<0.001$ \\
\hline
\end{tabular}

AlH, autoimmune hypothyroidism; DTC, differentiated thyroid carcinoma; ND, not determined.

a $\chi^{2}$ test for gender, independent samples $t$-test for age and thyroid parameters. Differences in MFI-20 scores were tested in a linear regression model, after adjustment for age and gender.

${ }^{\mathrm{b}}$ After log transformation of TSH levels. 
higher $\mathrm{L}-\mathrm{T}_{4}$ dose. DTC patients had significantly lower $\mathrm{T}_{3}$ levels (1.56 vs $\left.1.72 \mathrm{nmol} / \mathrm{l}\right)$.

Patients with AIH had significantly higher fatigue scores than DTC patients $(P<0.001)$, reflected by higher scores on all five MFI-20 subscales. Regression analysis showed that the effect of disease status (DTC vs AIH) on fatigue scores was not materially changed after adjustments for differences in thyroid parameters $\left(\mathrm{FT}_{4}, \mathrm{TSH}, \mathrm{T}_{4}\right.$, and $\mathrm{T}_{3}$ ) or general characteristics (BMI, age, or gender).

TSHR-Asp727Glu genotype status and thyroid parameters

In the total study population, the frequency of the TSHR-Glu 727 allele was $7.2 \%$ (Table 2). Distribution of genotype frequencies (Asp/Asp 85.6\%, Asp/Glu 14.4\%, Glu/Glu 0\%) showed no deviation from Hardy-Weinberg equilibrium $\left(X^{2}=1.67 ; P=0.20\right)$. Stratified by diagnosis (DTC vs AIH) also, no deviation from Hardy-Weinberg equilibrium was shown. In AIH patients, the Asp/Glu genotype frequency was slightly higher than in DTC patients ( 18.1 vs $10.7 \%)$.

In the total study population, heterozygous patients (45.1 years) were younger than wild-type patients (49.4 years). Heterozygotes and wild types had similar $\mathrm{FT}_{4}(18.2$ vs $18.1 \mathrm{pmol} / \mathrm{l})$ and $\mathrm{TSH}$ levels (0.60 vs $0.42 \mathrm{mU} / \mathrm{l}) . \mathrm{T}_{3}$ levels were higher in heterozygous than in wild-type patients ( $1.80 \mathrm{vs} 1.61 \mathrm{nmol} / \mathrm{l} ; P=0.006)$, despite similar serum $\mathrm{T}_{4}$ and $\mathrm{FT}_{4}$ levels. $\mathrm{T}_{4}$ dose did not differ between genotypes.

In DTC patients, no significant differences in clinical and biochemical parameters between genotypes were observed. Duration of cure, initial tumor stage, total radioiodine dose, recurrence frequency, and relative number of patients who had undergone a modified radical neck dissection were comparable between wild types and heterozygotes. Heterozygous AIH patients had significantly lower serum TSH levels than wild-type AIH patients $(0.89$ vs $1.40 \mathrm{mU} / \mathrm{l})$ and concomitantly higher serum $\mathrm{T}_{3}$ levels ( $\left.1.83 \mathrm{vs} 1.69 \mathrm{nmol} / \mathrm{l}\right)$.

\section{MFI-20 scores by TSHR-Asp727Glu genotype}

In the total study population $(n=278)$, average MFI-20 scores were slightly lower in four of five subscales in heterozygous patients, indicating less fatigue in these subjects. However, in none of the five subscales (general fatigue, physical fatigue, reduction in activity, reduction in motivation, and mental fatigue), the difference was statistically significant after adjustment for age and gender.

\section{Joint effects of genotype status and disease on fatigue: interaction analysis}

In order to determine whether the effect of genotype on fatigue varied according to the cause of hypothyroidism (DTC vs AIH), an interaction analysis was performed (Fig. 2).

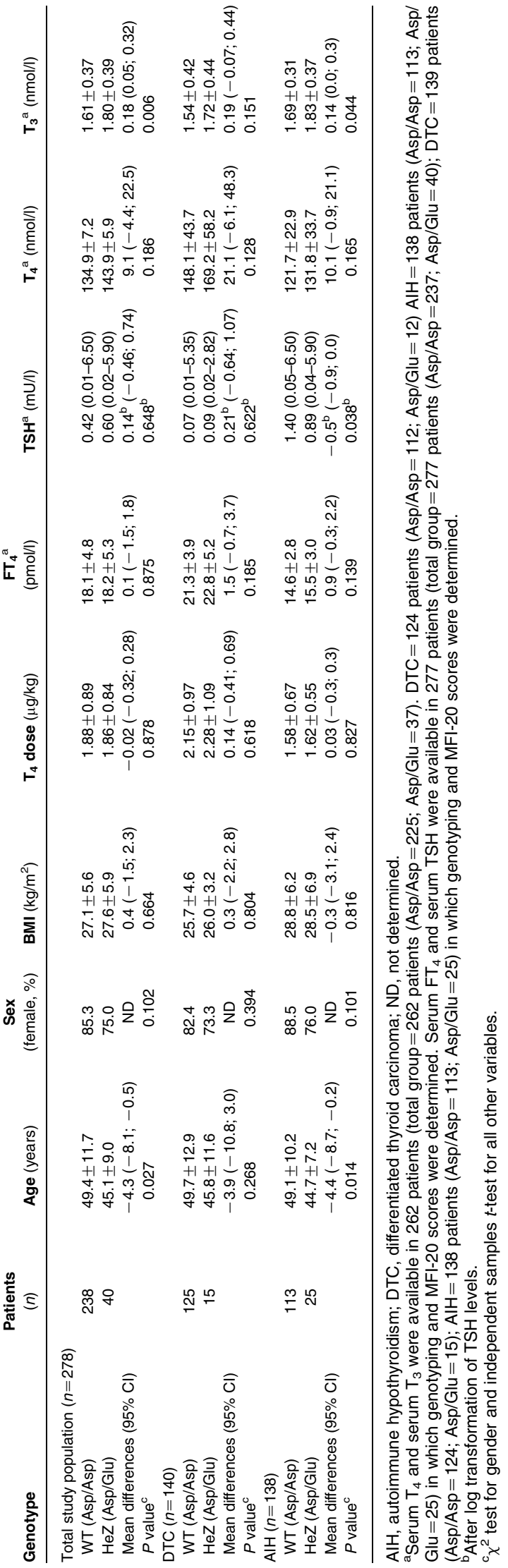


Wild-type DTC patients were set as the reference category and all analyses were adjusted for age and gender.

Compared with wild-type DTC patients, heterozygous DTC patients had lower scores on four of five MFI-20 subscales: general fatigue (MD -4.2; $95 \%$ CI $-6.5,-1.8)$, physical fatigue (MD - 3.9; $95 \% \mathrm{CI}-6.3,-1.5)$, reduction in activity $(\mathrm{MD}-1.6$; $95 \%$ CI $-4.0,0.7)$, and reduction in motivation (MD - 1.8; 95\% CI -4.0, 0.4), corresponding to $~ 20 \%$ lower scores on general fatigue and physical fatigue and $10 \%$ lower scores on the other two subscales.

Wild-type AIH patients scored clearly higher on all five MFI-20 subscales compared with wild-type DTC patients $(P<0.001)$ : general fatigue $(\mathrm{MD} 3.7 ; 95 \% \mathrm{CI}$
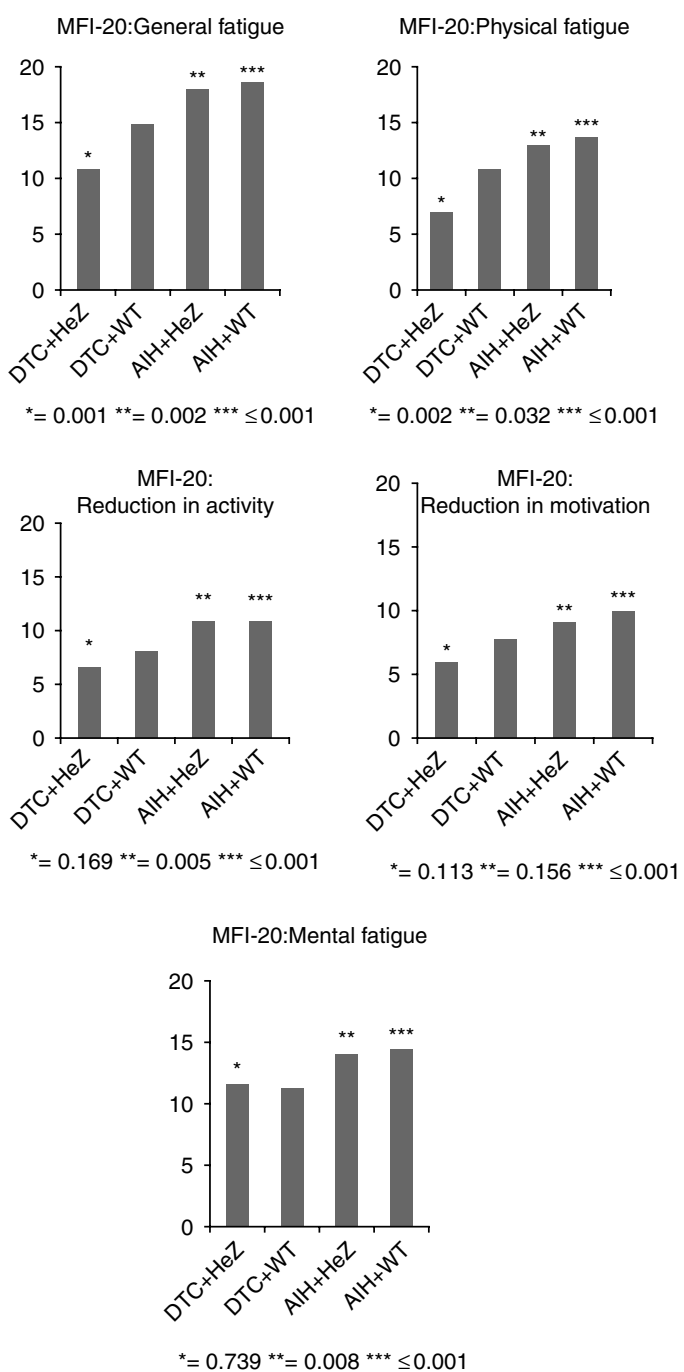

Figure 2 Joint effect of TSHR-Asp727Glu polymorphism and disease status on MFI-20 scores. MFI-20 scores by disease

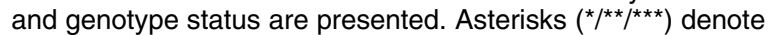
$P$ values corresponding to the difference with the reference group (DTC + WT). All MFI-20 scores were adjusted for age and gender. WT, wild-type; HeZ, heterozygous; DTC + HeZ $(n=15)$; DTC + WT $(n=125) ; \mathrm{AlH}+\mathrm{HeZ}(n=25) ; \mathrm{AlH}+\mathrm{WT}(n=113)$.
2.6, 4.8), physical fatigue (MD 2.9; 95\% CI 1.7, 4.0), reduction in activity (MD 2.7; 95\% CI 1.5, 3.8), reduction in motivation (MD 2.3; 95\% CI 1.3, 3.4), and mental fatigue (MD 3.1; 95\% CI 1.9, 4.4). Heterozygous AIH patients had similar MFI-20 scores as wild-type AIH patients.

Formal interaction analysis showed a less than additive effect of the TSHR-Asp727Glu polymorphism on MFI-20 scores in AIH patients in two subscales: general fatigue $(P=0.02)$ and physical fatigue $(P=0.046)$. Adjustment for thyroid parameters or BMI did not change these study results materially.

\section{Discussion}

This study evaluated the relationship between fatigue and origin of hypothyroidism in a population of 278 patients on thyroid hormone treatment therapy for different causes of hypothyroidism. In our study, fatigue and fatigue-related symptoms were more pronounced in AIH patients compared with DTC patients, reflected by significantly higher scores on all five MFI-20 subscales. As AIH patients were more obese and had a different thyroid hormone profile, results were adjusted for BMI and thyroid parameters, which did not alter study results. Therefore, our findings probably represent a disease-specific decrease in quality of life. Compared with data from the general population, AIH patients, but also DTC patients, reported more fatiguerelated symptoms (33). Patients with other autoimmune diseases (i.e. Sjögren's syndrome and rheumatoid arthritis) have similar low MFI-20 scores as we found in the AIH population (33). The disease-specific effect in AIH patients may be explained by autoimmunity. Recently, it was documented that complaints of fatigue in patients with Hashimoto's thyroiditis with elevated antiTPO antibodies are related to autoimmunity as such rather than thyroid function (34). The indication for thyroid function tests in AIH patients may be fatigue, which may cause overrepresentation of fatigued patients among all patients with AIH. Albeit, fatigue status was determined in patients on thyroid hormone replacement therapy for a longer period in a steady state of euthyroidism and not immediately after diagnosis of hypothyroidism.

In our study, a modest impact of the TSHRAsp727Glu polymorphism on fatigue was found in DTC patients only, an effect not seen in the more fatigued AIH patients. This finding should be interpreted with caution and replication is needed in order to establish a role of the TSHR-Asp727Glu polymorphism on fatigue-related symptoms in DTC patients with more certainty. It should also be emphasized that the study might be underpowered to detect a small effect of the polymorphism on fatigue-related symptoms in the total study population.

The TSHR-Glu 727 variant has been proposed to have higher sensitivity for TSH than the wild-type variant 
because less TSH is required to maintain normal $\mathrm{FT}_{4}$ serum levels $(19,20,21)$. TSH-suppressed DTC patients might have better conditions for an advantageous effect of a TSHR variant with an increased sensitivity because in a state of lower serum TSH concentration, a more sensitive TSHR could attribute to efficient local TSH effects. However, the functional significance of the TSHR-Asp727Glu allele has not yet been disentangled in all details $(35,36,37)$. A TSHR-mediated mechanism was proposed to be involved in stimulation of D2 expression by TSH in rat astroglial cells, cultured rat brown adipose tissue, and human osteoblasts $(7,8,15)$. D2 plays an important role in maintaining local bioavailability of thyroid hormone by catalyzing conversion of $\mathrm{T}_{4}$ to $\mathrm{T}_{3}(25)$. Because patients on replacement therapy with $\mathrm{L}-\mathrm{T}_{4}$ are presumably more dependent on deiodinase activity in peripheral tissue for their $\mathrm{T}_{3}$ production, extrathyroidal $\mathrm{D} 2$ enzyme activity in these patients could be of higher relevance than in non-diseased subjects. Given that expression of TSH mRNA has been reported in human brain $(12,14)$, an analogous positive role of TSH on D2 levels in human brain areas may be plausible. On the other hand, D2 expression in the human brain is highly localized and restricted to selective cell types such as hypothalamic tanycytes and additional non-neuronal cells (38). Interestingly, folliculostellate cells in the human anterior pituitary express both D2 and TSHR (39), but no data are available at present about neuronal or glial D2 and TSHR co-expression in human brain. TSHR activity may also affect other intracellular pathways, independent of intracellular $\mathrm{T}_{3}$ content.

Thyroid hormone profile differed substantially between DTC and AIH patients, reflected by significantly lower serum TSH and $\mathrm{T}_{3}$ levels in DTC patients on thyroid hormone suppression therapy. The significantly lower serum $\mathrm{T}_{3}$ levels may reflect the inhibition of deiodinase activity due to supranormal synthetic thyroid hormone dose (40). The TSHR-Asp727Glu allele was associated with higher serum $\mathrm{T}_{3}$ levels in our study population, which may support the concept of $\mathrm{D} 2$ stimulation by a TSHR-mediated mechanism $(7,8,15)$.

A large British community-based survey showed that patients on thyroid hormone replacement therapy for hypothyroidism due to different causes, with TSH and thyroid hormone levels in the normal RR, had considerably worse scores on psychological well-being, compared with their sex- and age-matched controls not on thyroid hormone treatment (1). Similarly, impaired neurocognitive functioning in hypothyroid patients has been described $(2,41)$. These findings emphasize the importance of research on determinants of well-being in patients with hypothyroidism.

In conclusion, this study demonstrated that patients with AIH were significantly more fatigued in contrast to patients with hypothyroidism after total thyroidectomy, which could not be attributed to thyroid or clinical parameters. A small and favorable effect of the
TSHR-Asp727Glu polymorphism on fatigue and fatiguerelated symptoms was found in thyroidectomized patients treated for thyroid carcinoma. This effect could not be found in patients with hypothyroidism due to autoimmunity. Replication of these results is warranted.

\section{Declaration of interest}

The authors declare that there is no conflict of interest that could be perceived as prejudicing the impartiality of the research reported.

\section{Funding}

This research did not receive any specific grant from any funding agency in the public, commercial or not-for-profit sector.

\section{References}

1 Saravanan P, Chau WF, Roberts N, Vedhara K, Greenwood R \& Dayan CM. Psychological well-being in patients on 'adequate' doses of L-thyroxine: results of a large, controlled community-based questionnaire study. Clinical Endocrinology 200257 577-585. (doi:10.1046/j.1365-2265.2002.01654.x)

2 Wekking EM, Appelhof BC, Fliers E, Schene AH, Huyser J, Tijssen JG \& Wiersinga WM. Cognitive functioning and wellbeing in euthyroid patients on thyroxine replacement therapy for primary hypothyroidism. European Journal of Endocrinology 2005153 747-753. (doi:10.1530/eje.1.02025)

3 Brokken LJ, Bakker O, Wiersinga WM \& Prummel MF. Functional thyrotropin receptor expression in the pituitary folliculo-stellate cell line TtT/GF. Experimental and Clinical Endocrinology \& Diabetes 2005113 13-20. (doi:10.1055/s-2004-830516)

4 Bahn RS. TSH receptor expression in orbital tissue and its role in the pathogenesis of Graves' ophthalmopathy. Journal of Endocrinological Investigation 200427 216-220.

5 Crisp MS, Lane C, Halliwell M, Wynford-Thomas D \& Ludgate M. Thyrotropin receptor transcripts in human adipose tissue. Journal of Clinical Endocrinology and Metabolism 199782 2003-2005.

6 Drvota V, Janson A, Norman C, Sylven C, Haggblad J, Bronnegard M \& Marcus C. Evidence for the presence of functional thyrotropin receptor in cardiac muscle. Biochemical and Biophysical Research Communications 1995211 426-431. (doi:10.1006/bbrc.1995.1831)

7 Morimura T, Tsunekawa K, Kasahara T, Seki K, Ogiwara T, Mori M \& Murakami M. Expression of type 2 iodothyronine deiodinase in human osteoblast is stimulated by thyrotropin. Endocrinology 2005146 2077-2084. (doi:10.1210/en.2004-1432)

8 Murakami M, Kamiya Y, Morimura T, Araki O, Imamura M, Ogiwara T, Mizuma H \& Mori M. Thyrotropin receptors in brown adipose tissue: thyrotropin stimulates type II iodothyronine deiodinase and uncoupling protein-1 in brown adipocytes. Endocrinology 2001142 1195-1201. (doi:10.1210/en.142.3.1195)

9 Feliciello A, Porcellini A, Ciullo I, Bonavolonta G, Avvedimento EV \& Fenzi G. Expression of thyrotropin-receptor mRNA in healthy and Graves' disease retro-orbital tissue. Lancet $1993 \mathbf{3 4 2}$ 337-338. (doi:10.1016/0140-6736(93)91475-2)

10 Francis T, Burch HB, Cai WY, Lukes Y, Peele M, Carr FE, Wartofsky L \& Burman KD. Lymphocytes express thyrotropin receptor-specific mRNA as detected by the PCR technique. Thyroid 19911 223-228. (doi:10.1089/thy.1991.1.223)

11 Bockmann J, Winter C, Wittkowski W, Kreutz MR \& Bockers TM. Cloning and expression of a brain-derived TSH receptor. Biochemical and Biophysical Research Communications 1997238 173-178. (doi:10.1006/bbrc.1997.7268)

12 Crisanti P, Omri B, Hughes E, Meduri G, Hery C, Clauser E, Jacquemin C \& Saunier B. The expression of thyrotropin receptor in the brain. Endocrinology 2001142 812-822. (doi:10.1210/ en.142.2.812) 
13 Grommen SV, Geysens S, Darras VM \& De Groef B. Chicken folliculostellate cells express thyrotropin receptor mRNA. Domestic Anima Endocrinology 200937 236-242. (doi:10.1016/j.domaniend.2009. 06.003)

14 Labudova O, Cairns N, Koeck T, Kitzmueller E, Rink H \& Lubec G. Thyroid stimulating hormone-receptor overexpression in brain of patients with Down syndrome and Alzheimer's disease. Life Sciences 199964 1037-1044. (doi:10.1016/S0024-3205(99)00030-2)

15 Saunier B, Pierre M, Jacquemin C \& Courtin F. Evidence for cAMPindependent thyrotropin effects on astroglial cells. European Journal of Biochemistry 1993218 1091-1094. (doi:10.1111) j.1432-1033.1993.tb18469.x)

16 Hanon EA, Lincoln GA, Fustin JM, Dardente H, Masson-Pevet M, Morgan PJ \& Hazlerigg DG. Ancestral TSH mechanism signals summer in a photoperiodic mammal. Current Biology $2008 \mathbf{1 8}$ 1147-1152. (doi:10.1016/j.cub.2008.06.076)

17 Yasuo S, Yoshimura T, Ebihara S \& Korf HW. Photoperiodic control of TSH- $\beta$ expression in the mammalian pars tuberalis has different impacts on the induction and suppression of the hypothalamohypopysial gonadal axis. Journal of Neuroendocrinology 201022 43-50. (doi:10.1111/j.1365-2826.2009.01936.x)

18 Peeters RP, van der Deure WM \& Visser TJ. Genetic variation in thyroid hormone pathway genes; polymorphisms in the TSH receptor and the iodothyronine deiodinases. European Journal of Endocrinology 2006155 655-662. (doi:10.1530/eje.1.02279)

19 Hansen PS, van der Deure WM, Peeters RP, Iachine I, Fenger M, Sorensen TI, Kyvik KO, Visser TJ \& Hegedus L. The impact of a TSH receptor gene polymorphism on thyroid-related phenotypes in a healthy Danish twin population. Clinical Endocrinology 2007 66 827-832. (doi:10.1111/j.1365-2265.2007.02820.x)

20 Peeters RP, van Toor H, Klootwijk W, de Rijke YB, Kuiper GG, Uitterlinden AG \& Visser TJ. Polymorphisms in thyroid hormone pathway genes are associated with plasma TSH and iodothyronine levels in healthy subjects. Journal of Clinical Endocrinology and Metabolism 2003 $\mathbf{8 8}$ 2880-2888. (doi:10.1210/jc.2002-021592)

21 van der Deure WM, Uitterlinden AG, Hofman A, Rivadeneira F, Pols HA, Peeters RP \& Visser TJ. Effects of serum TSH and $\mathrm{FT}_{4}$ levels and the TSHR-Asp727Glu polymorphism on bone: the Rotterdam Study. Clinical Endocrinology $2008 \quad 68$ 175-181. (doi:10.1111/j.1365-2265.2007.03016.x)

22 Heemstra KA, van der Deure WM, Peeters RP, Hamdy NA, Stokkel MP, Corssmit EP, Romijn JA, Visser TJ \& Smit JW. Thyroid hormone independent associations between serum TSH levels and indicators of bone turnover in cured patients with differentiated thyroid carcinoma. European Journal of Endocrinology 2008159 69-76. (doi:10.1530/EJE-08-0038)

23 Peeters RP, van der Deure WM, van den Beld AW, van Toor H, Lamberts SW, Janssen JA, Uitterlinden AG \& Visser TJ. The Asp727Glu polymorphism in the TSH receptor is associated with insulin resistance in healthy elderly men. Clinical Endocrinology 200766 808-815. (doi:10.1111/j.1365-2265.2007.02817.x)

24 Procopciuc LM, Hazi GM, Caracostea G, Dragotoiu G, Iordache G, Olteanu I \& Stamatian F. Correlation between the TSHRcAsp727Glu polymorphism and plasma thyroid stimulating hormone levels in Romanian preeclamptic women. Gynecological Endocrinology 201127 225-231. (doi:10.3109/09513590.2010.526658)

25 Bianco AC, Salvatore D, Gereben B, Berry MJ \& Larsen PR. Biochemistry, cellular and molecular biology, and physiological roles of the iodothyronine selenodeiodinases. Endocrine Reviews 200223 38-89. (doi:10.1210/er.23.1.38)

26 Appelhof BC, Peeters RP, Wiersinga WM, Visser TJ, Wekking EM, Huyser J, Schene AH, Tijssen JG, Hoogendijk WJ \& Fliers E. Polymorphisms in type 2 deiodinase are not associated with well-being, neurocognitive functioning, and preference for combined thyroxine/3,5,3'-triiodothyronine therapy. Journal of Clinical Endocrinology and Metabolism 200590 6296-6299. (doi:10.1210/ jc.2005-0451)

27 von Elm E, Altman DG, Egger M, Pocock SJ, Gotzsche PC \& Vandenbroucke JP. The Strengthening the Reporting of
Observational Studies in Epidemiology (STROBE) statement: guidelines for reporting observational studies. Journal of Clinical Epidemiology 200861 344-349. (doi:10.1016/j.jclinepi.2007. 11.008)

28 Appelhof BC, Fliers E, Wekking EM, Schene AH, Huyser J, Tijssen JG, Endert E, van Weert HC \& Wiersinga WM. Combined therapy with levothyroxine and liothyronine in two ratios, compared with levothyroxine monotherapy in primary hypothyroidism: a double-blind, randomized, controlled clinical trial. Journal of Clinical Endocrinology and Metabolism 200590 2666-2674. (doi:10.1210/jc.2004-2111)

29 Dekkers OM, Biermasz NR, Smit JW, Groot LE, Roelfsema F, Romijn JA \& Pereira AM. Quality of life in treated adult craniopharyngioma patients. European Journal of Endocrinology 2006154 483-489. (doi:10.1530/eje.1.02114)

30 Smets EM, Garssen B, Cull A \& De Haes JC. Application of the multidimensional fatigue inventory (MFI-20) in cancer patients receiving radiotherapy. British Journal of Cancer 1996 73 241-245. (doi:10.1038/bjc.1996.42)

31 Miller SA, Dykes DD \& Polesky HF. A simple salting out procedure for extracting DNA from human nucleated cells. Nucleic Acids Research 198816 1215. (doi:10.1093/nar/16.3.1215)

32 Wiersinga WM \& Chopra IJ. Radioimmunoassay of thyroxine $\left(\mathrm{T}_{4}\right)$, 3,5,3'-triiodothyronine $\left(\mathrm{T}_{3}\right), 3,3^{\prime}, 5^{\prime}$-triiodothyronine (reverse $\mathrm{T}_{3}$, $\left.\mathrm{rT}_{3}\right)$, and 3,3'-diiodothyronine $\left(\mathrm{T}_{2}\right)$. Methods in Enzymology 1982 84 272-303. (doi:10.1016/0076-6879(82)84024-X)

33 Barendregt PJ, Visser MR, Smets EM, Tulen JH, van den Meiracker AH, Boomsma F \& Markusse HM. Fatigue in primary Sjogren's syndrome. Annals of the Rheumatic Diseases $1998 \mathbf{5 7}$ 291-295. (doi:10.1136/ard.57.5.291)

34 Ott J, Promberger R, Kober F, Neuhold N, Tea M, Huber JC \& Hermann M. Hashimoto's thyroiditis affects symptom load and quality of life unrelated to hypothyroidism: a prospective casecontrol study in women undergoing thyroidectomy for benign goiter. Thyroid 201121 161-167. (doi:10.1089/thy.2010.0191)

35 Gabriel EM, Bergert ER, Grant CS, van Heerden JA, Thompson GB \& Morris JC. Germline polymorphism of codon 727 of human thyroid-stimulating hormone receptor is associated with toxic multinodular goiter. Journal of Clinical Endocrinology and Metabolism 199984 3328-3335. (doi:10.1210/jc.84.9.3328)

36 Nogueira CR, Kopp P, Arseven OK, Santos CL, Jameson JL \& Medeiros-Neto G. Thyrotropin receptor mutations in hyperfunctioning thyroid adenomas from Brazil. Thyroid $1999 \mathbf{9}$ 1063-1068. (doi:10.1089/thy.1999.9.1063)

37 Sykiotis GP, Neumann S, Georgopoulos NA, Sgourou A, Papachatzopoulou A, Markou KB, Kyriazopoulou V, Paschke R, Vagenakis AG \& Papavassiliou AG. Functional significance of the thyrotropin receptor germline polymorphism D727E. Biochemical and Biophysical Research Communications 2003301 1051-1056. (doi:10.1016/S0006-291X(03)00071-8)

38 Alkemade A, Friesema EC, Unmehopa UA, Fabriek BO, Kuiper GG, Leonard JL, Wiersinga WM, Swaab DF, Visser TJ \& Fliers E. Neuroanatomical pathways for thyroid hormone feedback in the human hypothalamus. Journal of Clinical Endocrinology and Metabolism 200590 4322-4334. (doi:10.1210/jc.2004-2567)

39 Fliers E, Unmehopa UA \& Alkemade A. Functional neuroanatomy of thyroid hormone feedback in the human hypothalamus and pituitary gland. Molecular and Cellular Endocrinology 2006 251 1-8. (doi:10.1016/j.mce.2006.03.042)

40 Kohrle J. Local activation and inactivation of thyroid hormones: the deiodinase family. Molecular and Cellular Endocrinology 1999 151 103-119. (doi:10.1016/S0303-7207(99)00040-4)

41 Dugbartey AT. Neurocognitive aspects of hypothyroidism. Archives of Internal Medicine $1998 \mathbf{1 5 8}$ 1413-1418. (doi:10.1001/ archinte.158.13.1413)

Received 8 June 2012

Revised version received 17 August 2012

Accepted 18 September 2012 